\section{高分子科学のゆくえ 新ポリマーの可能性}

\section{POLYMER TOMORROW 一高分子若手研究者の意見 2}

\section{*ライフサイエンスの危険性の側面}

従来「高分子科学のゆくえ」と いらような類のテーマは, 本誌上 で既成の大家によって論じられて きた.今回は若手研究者にそのよ らなテーマで発言が求められたの は，科学への幻隇が言われるこの 時代に，夢物語ではなく現実性の ある具体的な提言を，編集委員会 が若い研究者に期待されたからで あろら。これからの高分子科学が ライフサイエンスを目指すである う，といらことは，一般的な常識 であって今さら言うまでもない。 ライフサイェンスと総称されるも のの各々について，具体的なアプ ローチの方法が問題なのである. だがそれを見通して予言すること は容易ではない, 私自身, 名案が あれば承りたい側であって，とて もそのよらな予言をする柄ではな いしかし，せっかく与えられた 機会でもあるので, 高分子科学は どらあるべきか，といらような意 味で, ライフサイェンスの危險性 について，日頃考えていることを 記してみたい。

科学技術は人類のためになるも のでなければならない. 近年ライ フサイエンスがクローズアップさ れてきたのも，人類の幸福のため であろら、しかし，私が何よりも 恐ろしいと思うのは，ライフサイ エンスが進歩した喷には，遺伝を ろう。

コントロールしたり，人の思考ま でコントロールできる可能性があ るが，そのとき人類が犯す過ちで ある.その被害は，原爆やいまの 公害が及ぼした被害の比ではなか

医療材料への高分子の利用は， ライフサイェンスの一環として注 目され，これからの発展が期待さ れている. Dr. Kolobow はアメ リカの $\mathrm{NIH}$ (National Institute of Health) で人工心肺の開 発をしている研究者であるが，氏 の話が私には非常に印象に残って いる．私は人工腎臓を見るのもそ のときが初めてという，全くの門 外漢であった，そして，この分野 の研究者の最終目標は, 人の臓器

\title{
*生体高分子の特異性の解明
}

生体高分子は，生命現象の特異 性の発現される最小単位であると 考えられている.ここでいら特異 性には，構造の特異性，識別の特 異性，機能の特異性がありより 高次の生命現象も，これらの特異 性の複雑な組み合わせにより説明 できると考えられる。

1）構造の特異性について 生体高分子, 二次, 三次, 四次 構造として一定の構造を持つこと は,ポリペプチドの研究，X線構造
が損傷された場合に，交換して体 内にセットできるような人工蔵器 をつくることだろらと，素人考兄 で想像していた，氏はそのような 考えを否定して，本来の臓器が病 いに冒されて機能が低下したとき に, その臓器の回復を助けるため に, 人工臓器を補助あるいは代用 として使えるようにするのが目的 だと話された，造物主に人智はは るかに及ばないというのが技術の 現状なのであろらが，氏の奢らな い考え方に，私は好感をもった。 また，氏の性格についても，懷疑 的ないしは深謀遠慮型の東洋的な ものを感じて安堵感をお゙゙えた。 というのは，猪突猛進型の研究者 によって，もらかるからといらよ らな理由でライフサイエンスが研 究され，成果が利用されたのでは， 人類は破隇すると思らからであ る.

ライフサイェンスは両刃の刃で ある，研究者の謙虚な態度，冷静 な判断が望をれる。

（東大工学部合成化学科

勝木紘一)
解析によって確立してきた。今後 の課題としては，一次構造と高次 構造の相関関係について, 動的構 造の解明が残されている。構造の 特異性之機能, 分子識別の特異性 との関係を理解するには，構造の 動的なふるまいについての知見 が必須であろう。これらの解明 は, 生体起源高分子の研究 と共 に, シークェンスの決まった合成 高分子により, 三次構造, 高次構 造（もしあれば）のモデルを用い 
た研究も有効であると思われる。

2）識別の特異性について

生体高分子の識別の特徵は, 特 に高分子が高分子を識別するとい う点にある。とれを理解するに は，高分子と高分子の相互作用に ついての知見が決定的に必要であ る.この面では, 生体起源の高分 子の相互作用のみでなく，簡単な 合成高分子を使って，基憷的なデ 一タを積み重ねることが有効であ ろら、複雑な高分子ぞうしが拉 そ識別するためにはなずあらく 識別し，その後ロックーキーのよ うに扣互いを流っきりと認識する といら 2 段階を考觉るのがもっと むらしい，構造变化についての動 的な知見が，識別の特異性にと。 て重要であると考觉るゆえんであ る。

3）機能の特異性について

機能の特異性は，特に酵素と基 質との反応を中心に多くのことが
調べられている、しかしまだ高分 子であるために特異的に起こる反 応の突態については，十分解明さ れていない，生体起源高分子と基 質との反応について，分子に即し て反応の実熊を明らかにする研究 が，期待される。同時に，構造 機能との関係をよく理解するため に, 比較的簡単な一定の檴造を持 つ環状ペプチドなどの機能と構造 の関係を十分研究する必要がある のではないだろらか。

以上, 生体高分子の特異性の解 明の問題のみに絞って今後に残さ れた課題を述べた。最近特に人工 酵素なぞ, 生体高分子の工業的利 用の発展, 生体高分子物性学の進 歩は著しく，その面でも生体高分 子研究は，一時代を画そうとして いる. 次の 4 半世紀涪託すわれわ れの夢は大きい.

（自治医科大物理学科

木原 裕）

\section{*酵素モデルの補酵素系高分子触媒}

筆者らは数年来, 高分子を利用 するといら立場から，醥素反応を 意識した高分子触媒の研究に從事 してきた、いわゆる、「酵素モデ ル」の研究である.しかし, 酵素 反応のモデルとして高分子触媒を 考える時, 何が，どこまで「モデ ル」として意味があるか，といら 問題は依然として暧昧であるし， 高分子を用いる反応の多くに漠然 と酵素モデルの名称を冠しても仕 方がないような気がしていた。

筆者は元来，ミセルに興味を持 っていた，しかし，イオン性モノ マーと酵素類似活性を持つモノマ 一の共重合体を合成したが，ミセ
ル系活ど反応性が向上する例は見 当らなかった。これはポリマー主 鎖に沿って共有結合でつなぎとめ られている電荷の密度が, ミセル 系に比べて蹯であるためと考兄ら れる. 最近, 脂肪族長鎖を導入す ることにより，ポリマー系でるミ セルをしのぐ効果を発現すること が明らかになりつつある、いわゆ る,ポリソープ(ポリマーミセル) である.これは生化学的発想から すれば, 一次構造のみでなく高次 構造の規制が触媒活性に関与して いるといらことになるであるう．

ところで, このようなイオン性 の場の効果を最も敏感に反映する
酵素反応は酸化還元系ではないだ ろらか，と考觉た．酸化還元反応 をつかさどる酵素のほとんどは補 酵素（あるいはビタミン：cofactor）と関係している. 興味あ ることに, これらの補醳素の官能 基は「反応の場」を提供すると考 えられるアポ酵素が存在しない系 でもある程度の活性を示すことが 多い、したがって, 補酵素自身の 反応メカニズムがそのま酵素反 応のメカニズムと考觉られるの で，むはや「モデルとは何か」と いらわずらわしい問題に悩まされ る必要はない, 端的に言えば, 補 䤃素の官能基の反応メカニズムは 非常に有機化学的研究対象である と同時に，酵素反応そのものに も，直接かかわっていることにな る.

このよらな経由から, 筆者は最 近, 補酵素之高分子のむつ特徵を 利用して，新しい高分子触媒系が 開拓できるのではという期待を抱 くよらになった，補䤏素の官能基 は比較的単純な輔造ながら，自然 により巧みにデザインされてい る. 残る問題はこの官能基を人為 的に「巧み」に利用することであ る、筆者は合成ポリマーにより， 活性の調節や，基質の選択性を比 較的自由にコントロールできるも のと考穴ている，また，高分子触 媒それ自身への興味を超兄て， 「触婪」として反応汇用いる立場 も非常に重要であると考兄てい る. (九大工学部 新海征治) 


\section{*機能性高分子の目指すもの}

今後の高分子科学などといら大 それた題ではとても書き出せない ので，ここでは小生の仕事とも関 係のある機能性高分子のごく近い 将来の方向をらかがって見たい。

大量生産，大量消費を目指した 高度成長体制が問い直され人口抑 制が叫ばれている現在, 高分子研 究の流れも汎用ポリマーからより 知識集約型の，例えば機能性高分 子へと移ってきたのも半ば必然と い兄よう，機能性高分子は高分子 触媒，高分子試薬，高分子電解質 などの機能によって分類するのが 普通であろらが，今，高分子鎖の 特性によって次の 2 種にわ外て考 える、第一の型は高分子量のポリ マーの持つランダム性を利用する もので，いわば統計的な機能性高 分子である、先に挙げた例杂初め 今までに研究されてきた多くの機 能性高分子がこの中に入る.この よらな系は今までの高分子科学の 流れに沿ったものであり，種々の 実験結果はこれまでに発展してき た高分子鎖の統計理論を用いると 解釈可能になると考えられる.こ の方法で高分子鎖の機能（高分子 効果) に関する一般的原理を見い だし，種々の応用へと広げること は今後とも重要な課題であろら.

一方, 統計的な機能からは, 例元 ば酵素に見られるような高い効率 や選択性などの高度に特異的な現 象は期待できない，高分子效果の 特異性を高めるためには, 場とし ての高分子鎖が特異的でなければ ならない，そのよらな系として最 近, 環状ペプチドなどの構造(コン ホメーション) の自由度の小さい ものが研究されてきた，このよう
な系としてはほかに種々のオリゴ ペプチド,オリゴ粕, オリゴ核酸, また $\alpha$-ヘリックスなどの特定の 構造をとるポりアミノ酸や多糖類 などが考觉られる、これらのかた い鎖の場ではかなり特異的な高分 子效果が期待されらるが，その中 には「全く反応しない」という特 異性も多く含まれている。このよ らな当りはずれの大きな研究を効 率よく進めるための方針は，酵素
反応のよらな生物化学の領域から 得られるかもしれないし，あるい はコンホメーション計算のような 物理化学的知識から得られるのか もしれない．真に特異的な高分子 効果を見いだすためには「笑験を すれば何か結果が出るだろら」と いらょらな甘い考㝋を捨て, 生物 化学者や物理化学者との協力のも とに，過去の知識を集約した形で 可能性を追求する必要があると考 觉れる。

(京大工学部 突戸昌彦)

\section{*高分子液晶の今後の課題}

ポリアミノ酸液晶がロビンソン などによって研究されて以来すで に20年になるらとしている.数多 くの研究発表があるがサーモト口 ピック液晶と比較するとい屯だ不 明な点が多く，理論的な取り扱い にいたってはフローリーの棒状分 子の相分離の理論以外, 絶無に近 いといってもよい。ここでは構造 を中心とした問題点をあげてこの テーマに関心のある方々のご批判 を仰ぎたい。亦ずポリアミノ酸液 晶は外力がなく，かつ単一の溶媒 中では本質的にコレステリック構 造をとる事が知られているが，な ぜだろらか（またねじれ構造を安 定化させている力はいかなるるの であるらか.サーモトロピック系 では双極子一四重極子相互作用の 2 次の摂動によるとするグーゼソ の説があるが，溶媒を含み，かつ 分子間距離の大きいこの系では， とてもそのよらな近距離の力であ るとは考えられない，われわれは これを定性的に steric effect で あるとして説明を試みたが，実際 にはもっと定量的に分子間相互作
用から説明すべきであろう。

液晶構造の特徵は，それが溶媒 の種類に強く依存する点にある. コレステリックのねじれ角（また はピッチ）の絶対值が異なるだけ でなく、ねじれの向き自身が溶媒 によって異なる。このよらな溶媒 効果をどら考えたら良いのだろう to.

コレステリックのねじれ角はま た，温度，濃度に依存するだけで なく，両者の効果を分離して考え られないところにとの困難さがあ る. 通常測定される濃度ではピッ チは温度の増加にともなって増加 し，サーモトロピック系と逆の傾 向を示すが濃度を上げていくとピ ッチ温度上昇にともなって減少 して行く可能性がある.この事は サーモトロピック系でのコレステ リック一ネマティック混合系と類 似の挙動を示し,リオトロピック 系の溶媒をあたかもサーモトロピ ック系のネマティック物質之考光 る事比って見かけ上巽なってい る二つの系を統一した理論が考党 られないだるうか。 
ポリアミノ酸液晶の諸問題は結 局, Polymer-Polymer 护よび Polymer-Solvent の分子間相互 作用，分子運動のレベルで考克る 事のできる段階にきているように 思う。またこのような秩序構造を とる系では高分子濃厚溶液といら 困難な問題を単純化できるという 側面もあるのではなからうか。

最後に, 生体系に招いて子液晶 構造の発現が知られているが，生 体機能と液晶構造との関係は, 高 分子液晶の研究の発展の上に, 最 も興味ある問題として浮かび上が ってくるのではなからうか.

（東写大工学部

森 紀夫)

れご意見・ご感想を……1月号と 本号に若干研究者の「高分子科学 のゆく光/新ポリマーの可能性」 を揭載しました。

若手研究者の意見に対して，会 員読者からのご感想，ご意見を括 寄せいただきたいと思います。

字数 $=$ 約 1,000 字 原稿締切= 2 月 15 日 宛先 $=\lceil$ 高分子」編集係

*無機ポリマーの役割に期待

「今後の高分子化学のあるべき 姿」について編集部から意見を求 められたが，化学をかじり初めた ばかりの人間として, 私の所属す る講座の中で議論されていること を書いてみる。

第一に，省資源・省エネルギー を意識して高分子を合成するとい らことが考えられると思ら，地球 上に最も多く存在する元素は酸素 で，次がケイ素である，酸素とケ イ素を主体にしたポリマーをでき るだけエネルギーを使わない方法 で（例えば常温・常圧下で水のよ らに豐富に存在する溶媒を使。 て）合成することが必要であると 考えられる。こうして合成した䇺 機ポリマーと現在盛んに用いられ ている有機ポリマーとをらまく組 み合わせたり，使い分けたりして いくことが必要であると思われ る、また公害防止の意味からも， それらのポリマーが容易に再生で きるといらことも必要条件の一つ と思う。
第二に，いわゆるファインケミ カルな方向が考学られる.「生体 膜」とか门人工酵素」といらょう な生体高分子への関心の高まりは 言うまでもない，私どもの講座で は酸化物の焼結や結晶成長の研究 も行なっているが，見方によって はこれらをポリマーと見なすこと ができる。これらの無機ポリマー は現在のところかなり高温で合成 されているのだが，「無機結合剤」 を用いることによって，もっと低 い温度で合成できるといら報告が ある，さらに進んで，「人工酵素」 のよらなものによって, 常温・常 圧下で，陶器やガラスのような然 機ポリマーが合成されれば，これ らは酸素とタイ素が主体のポリマ 一なので省資源につながるし，エ ネルギーも節約でき，また用いる 触某はごく微量ですむ（ファイン ケミカル）から，本気でこういっ た方向にとりくむのも一つの道か と思われる。

（名大工学部 森 吉生）

製品紹介

煙濃度測定器 $\mathbf{D}$ 型

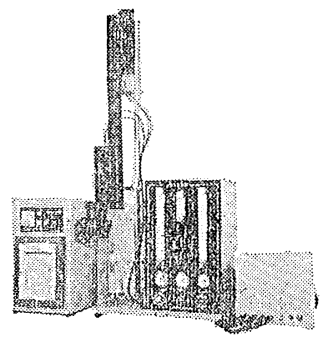

本器は各種然焼試験器に接続して, 燃焼中の煙濃 度を測定，記録します。
エアノズル方式光学系を用い，ススなどの污れに よる煙濃度への影響が極めて少なく，また温度補償 回路を備えたシリコン光電池式であるため，熱の影 響なし. 光源ランプ点灯電源はオールトランジスタ 方式で安定が良好. 写真は, 酸素指数方式然烧試験 器と組合わせたもの. (ON-1D型)

光源部：A光を平行光線にして投光

受光部 : フィルタを通過した光を光電池により電 気信号に変換光路長 : $500 \mathrm{~mm}$

記録計：自動平衡式, 目盛範囲は 0 100\%, 記録

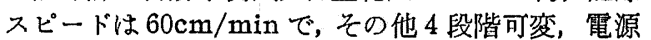
は AC 100V.

価格 $¥ 850,000$ 一(ON-1D型は $¥ 1,300,000)$

\section{スガ試験機楼式会社}

（旧 東洋理化工業株式会社） 